\title{
Powerlessness in Self-Actualization of Street Vendors in Palangkaraya City
}

\author{
Sriyana $^{1}$, Ishomuddin ${ }^{2 *}$, Rinikso Kartono ${ }^{3}$, Wahyudi ${ }^{4}$ \\ ${ }^{1}$ Doctor Candidate of Social and Political Sciences of University of Muhammadiyah Malang, \\ ${ }^{2}$ Professor of Sociology of Islamic Society of University of Muhammadiyah Malang, \\ ${ }^{3}$ Doctor Social Welfare Actors of the University of Muhammadiyah Malang, \\ ${ }^{4}$ Doctor of Sociology of University of Muhammadiyah Malang
}

\begin{abstract}
*Corresponding Author: Ishomuddin, Professor of Sociology of Islamic Society of University of Muhammadiyah Malang. His diligence in writing and spreading his knowledge was proven by publishing his writings in various national and international journals.
\end{abstract}

\begin{abstract}
Powerlessness is the inability to effectively manage emotions, skills, knowledge and material resources to achieve personal satisfaction according to existing social institutions. Powerlessness is not caused by the absence of one's potential, but rather there are obstacles that prevent this potential from developing which is called a power block. The powerlessness of street vendors reduces their income levels and welfare levels, so the government must take a role in the development of street vendors through skills training, capital assistancelfacilities and business development guidance. This study aims to understand the powerlessness in self-actualization of street vendors in Palangkaraya City. This study uses a qualitative approach to data collection techniques using observation, interviews and documents. While data analysis uses the interactive analysis model of Miles and Huberman.
\end{abstract}

Key words: Powerlessness, Self Actualization, Street Vendors.

\section{INTRODUCTION}

The dynamics of the informal sector in Indonesia cannot be separated from the development paradigm. Development models that are based more on economic growth, industrialization, agricultural mechanization (read: green revolution), and urban development tend to give birth to inequality (Pitoyo, 2007). Cities are more prosperous than villages, causing urbanization to flow. When the labor force increases and employment in the formal sector is not able to compensate, then they work improperly, in whatever small business field to survive (Pitoyo, 2007; Alisjahbana, 2006; Setiono, 2004). As a result, the informal sector gradually emerges or is often called the underground or shadow economy (Lamba, 2011).

The informal sector such as street vendors can be a buffer of economic system distortion, but also one of the problems in urban spatial planning. Street vendors are always active in public spaces such as sidewalks, city parks, or on other public spaces. This activity will reduce the quality of public spaces, because some public spaces have been taken over by street vendors. The existence of street vendors often causes chaos. Street vendors try to actualize all abilities to achieve profits, as well as trying to attract buyers in various ways. However, these efforts often meet obstacles that cause helpless street vendors. The powerlessness of street vendors can be seen from three aspects namely the individual aspects, aspects of habits and aspects of government policy.

Individual powerlessness is caused by lack of ability, knowledge, skills and adaptation. Powerlessness in the aspect of ability can be approached by social cognitive theory that emphasizes the importance of unique human characteristics (attributes), namely the nature of symbolization, self-regulation, selfcorrection, and learning ability. Morissan (2010) states that humans have the ability or capacity to understand and use various symbols so that they can store, process, and transform experiences into cognitive models that will guide them in taking action or making decisions in the future (Kusuma \& Putri, 2012). The implication, street vendors must have certain characteristics understood by consumers, both the characteristics of merchandise, places to sell and the supply system. 
The powerlessness of street vendors can also be seen from cultural aspects. Culture is all systems of values, norms, beliefs and all the habits and customs that have become ingrained that have the power to form patterns of behavior and attitudes (from within) (Wirutomo, 2013). Thus the cultural empowerment of street vendors means that there is a value system that is the basis, habits and ways of thinking street vendors in conducting trade transactions and providing services to customers.

Solomon stated that helplessness is the inability to effectively manage emotions, skills, knowledge and material resources to achieve personal satisfaction in accordance with existing social institutions. Powerlessness is not caused by the absence of one's potential, but rather the obstacles that prevent the potential to develop, which is called a power block (Kartono, 2011).

Power blocks include various actions, events or conditions that interfere with individuals developing effective personal and social skills. Power blocks operate at primary, secondary and tertiary levels. At the primary level, power blocks are negative judgments, stigma and pressure that interfere with the development of personal resources such as self-respect or cognitive skills. At the secondary level, indirect power blocks occur when personal resources are limited by blocks at the primary level. Tertiary level, inderect power block occurs because of limited personal and interpersonal resources and technical skills in making assessments of social roles. Direct power block occurs when negative assessments are applied directly by agents from major social institutions (Kartono, 2011).

In the context of helplessness in self-actualization of street vendors, Solomon's power blocks theory is deemed incompatible with the conditions of street vendors helplessness in Palangka Raya City, namely, first, powerlessness is not solely due to the disruption of effective personal and social skills. Second, street vendors have been stigmatized as social groups that create traffic clutter and congestion. Third, Solomon's theory is built in the African social and cultural context, so for nonAfrican contexts this theory is not necessarily able to explain and understand the powerlessness in the self-actualization of street vendors. Based on this description, this study aims to understand the powerlessness in self-actualization of street vendors in the City of Palangka Raya.

\section{LiTERATURE REVIEW}

\subsection{Powerlessness}

Seeman (1982) provides a definition of helplessness, namely: expectations or possibilities possessed by someone whose behavior alone is not able to determine whether or not the results or assistance sought are achieved. Or more can be understood by describing the relationship of a human being with a large social order. From Seeman's definition, helplessness has two aspects, namely: first one does not have confidence in changing the course of his life. This means that outsiders, the surrounding environment, surrounding communities, the authorities do not pay attention to their basic needs and they themselves cannot change even though they have tried. This first aspect is more directed at external factors or comes from outside oneself. While the second aspect is that helplessness is caused by the individual himself. This aspect is more directed at internal factors, which can be characterized as being apathetic, hopeless, losing hope, depression, self-exclusion and lack of motivation.

Another notion of helplessness is according to Kalekin and Fishman in Senekal (2010) that helplessness is the distance that exists between what someone wants to do and what someone feels capable of doing. The opinion of Kalekin and Fishman was also clarified by Seeman who said that helplessness is related to ability and disability, both from within oneself and due to influences from outside the person (Wenovska, 2016).

In addition to the above opinion, Chambers (1994) included powerlessness in 5 (five) elements of the poverty trap consisting of: (1) poverty, (2) physical weakness, (3) isolation or levels of isolation, (4) vulnerability and (5) helplessness. According to Chambers in Suyanto (2013) that the helplessness of the poor is caused by their powerlessness in dealing with those in power or those who have power.

Powerlessness is the key in poverty traps aside from vulnerability, this is because the inability of a person or group to change their destiny from poverty will worsen their own situation. In addition, there is the added influence of outside power who does not want the poor people to change or the ruler commits fraud by saying they will make a change but only changes the ignorant community instead to become poorer due to wrong policies (Wenovska, 2016).

\subsection{Self-actualization}


Self-actualization according to Maslow (1970) is the desire possessed by individuals to become fully themselves, and actualize their potential, so that the need for self-actualization according to Maslow is a desire to continue to realize self-potential or it can be said the desire to become what we can. Selfactualization is an innate process by which people tend to grow spiritually and realize their potential. Only a few people have managed to actualize themselves fully, but many are heading in that direction. Interestingly, the thought of self-actualization was first proposed by Carl Jung (Friedman \& Schustack, 2006).

According to Maslow self-actualization is the culmination of a hierarchy of human needs, namely the development or realization of potential and full capacity. Self-actualization needs are the highest level needs, these needs will arise if other needs are met properly. Maslow marks the need for selfactualization as an individual's desire to be a person in accordance with the desires and potential he has or the desire of an individual to perfect himself through the disclosure of his potential (Hambali \& Jaenudin, 2013).

Jung in O'Byrne \& Angers (1961) that self-actualization is an individual's desire to ultimately replace the ego with self to stabilize his personality. Jung in Boeree (2008) revealed that by no longer focusing on the ego, the individual will not be selfish, and look at other people better. Whereas Rogers defines self-actualization as a process of being oneself and developing unique psychological traits and potentials. Self-actualization will be helped or hindered by experience and by learning especially in childhood. Self-actualization will change in line with the development of one's life when, reaching a certain age (adolence) someone will experience a shift in self-actualization from physiological to psychological (Hambali \& Jaenudin, 2013). Rogers believes, humans have one basic motive, namely the tendency to actualize themselves. This tendency is the desire to fulfill the potential possessed and reach the highest stage of human-beingness (Hambali \& Jaenudin, 2013).

\subsection{Street vendors}

According to McGee and Yeung (1997) mention street vendors as hawkers are people who offer goods or services for sale in public places, especially sidewalk streets. Likewise, Karafir (1977) argues that street vendors are traders who sell in public places such as curbs, parks, storefronts and markets without or having a business permit from the government. From these two opinions it can be concluded that the street vendors are those who do business in public places without or having permission from the government. Bromley (Manning and Tadjuddin, 1991) state that street vendors are the most real and important occupations in most cities in Africa, Asia, the Middle East, or Latin America. But despite its importance, street vendors receive little academic attention compared to other major occupational groups.

Some typical characteristics of street vendors raised by Suyanto (2005) are: First, the pattern of distribution of street vendors generally approaches the center of the crowd and without permission to occupy zones that should be public property. Second, street vendors generally have a very flexible social resistance to various pressures and control activities. Third, as a business activity, street vendors generally have a very loose labor absorption mechanism. Fourth, most street vendors are migrants, and the process of adaptation and their existence is supported by forms of patronage relations based on the ties of similarity factors of origin. Fifth, street vendors do not have the alternative skills and expertise to develop new business activities outside the urban informal sector.

\subsection{Theory of Social Change}

Sztompka (2004) says that social change is a change that occurs in a social system that causes differences from a system in a certain period of time. Social change can occur both in whole and in part social components. This condition is caused by several triggering factors, namely: (1) main elements (number and type of individuals, and their actions), (2) relationships between elements (social ties, loyalty, integration, relationships between individuals), (3) functioning elements in the system (the role of individuals in carrying out their work), (4) maintenance of boundaries (conditions of acceptance of individual groups, recruitment principles in organizations), (5) sub-systems (number and types of parts), and (6) environment (natural conditions and geopolitical location) (Sztompka, 2004)

The analysis from Sztompka above, corroborated by Narwoko, et al (2010) which explains that social change is related to aspects of people's lives as well as existing social phenomena. Where social 
change contains three dimensions of change, namely: (1) structural dimension, is change related to power, both power over territory and power related to the status or role it has, (2) cultural dimension, is change that occurs due to new culture that is related to human behavior so that its presence is sometimes not realized so that it often causes conflicts in the community, and (3) interactional dimension, is a change that occurs due to the presence of people who interact actively by interpreting symbols in communication.

Every social change always has dimensions attached to it. According to Himes and Moore there are three dimensions of social change, namely:

1. Structural dimensions are changes in the structural level of society related to new roles, changes in social class and changes in social institutions. The form of change is the increasingly shrinking or developing levels of roles regarding behavior and power, categorization of roles, the modification of communication channels as well as the changes in types and usability of role functions as a result of structural changes.

2.Cultural dimensions are cultural changes that occur in society. These cultural changes include:

a.Cultural innovation is an internal component that can bring about social change in society, usually involving the discovery of new technology.

b.Diffusion is an external component that can drive the emergence of social change. Diffusion can be in the form of the inclusion of other cultures that can influence cultural changes in a society.

c.Integration is a form of social change that is more subtle due to the unification of cultural elements that meet each other so as to create a new culture.

3. The interactional dimension is the impact of changes in social relations in society, which include:

a.Changes in frequency are concerned with the intensity of individual meetings due to new technology.

b.Changes in social distance are shifts face to face between individuals in interacting as a result of technological change.

c.Intermediary changes are changes in the mechanism of work of individuals online so that individuals are no longer dependent on others in the process of sending information.

d.Changes in rules or patterns are a form of changing patterns or rules as a result of the development of society.

e. Changes in the form of interactions are interactions between individuals that are not as rigid as the past which is done by meeting face to face (Suntari, 2016).

\subsection{Empowerment Theory}

Conceptually, empowerment or empowerment, comes from the word power, which means power or empowerment. The concept of empowerment begins with strengthening social capital in the community (groups) which includes strengthening social capital (trust, rule-abiding, and networking). If we already have strong social capital, it will be easy for us to direct and manage the community and easily transfer knowledge to the community.

Empowerment refers to the ability of people, especially vulnerable and weak groups so that they have the strength or ability to (a) fulfill their basic needs so that they have freedom, in the sense of not only being free to express their opinions, but free from hunger, free from ignorance, free from pain ; (b) reach productive resources that enable them to increase their income and obtain the goods and services they need; and (c) participate in development processes and decisions that affect them (Suharto, 2005).

Empowerment is a way by which the people, organizations and communities are directed to be able to control (or have power over) their lives (Rappaport, 1984). Meanwhile, according to Parsons, et al. that empowerment is a process by which people become strong enough to participate in, share control over, and influence on, the events and institutions that affect their lives. Empowerment emphasizes that people acquire enough skills, knowledge, and power to influence their lives and the lives of others they care about (Parsons, et al., 1994). 


\subsection{Theory of Poverty}

According to Benjamin White in Dillon and Hermanto (1993) that poverty is an inequality in measuring the level of welfare of a community that exists in one region compared to other regions. But poverty does not mean that street vendors can not afford to try. As Kotze argues in Wisdom (2004) that poverty experienced by the community actually has a better ability to obtain a source of income from the opportunities or conditions that exist. This means that street vendors try to release the label of the inability to the conditions of poverty they experience.

Robert Chambers (1983) explains that poverty is an integrated concept that has five dimensions, namely: (a) poverty, is the inability of income to make ends meet, both for people who have income and those who do not have income, (b) powerlessness, is the impact of the low ability of income to social power in order to get equal rights and justice for a decent life experienced by someone, (c) vulnerability to face emergency situations, is a condition of a person's inability to deal with situations and conditions that require unexpected income allocation for resolution, (d) dependence, is a form of income disability that causes a person's social power limitations to others so that there is a very high dependency, and (e) alienation, is a geographical factor or location that causes a person to be poor. The location factor that causes poverty is because it is far from the economic center, lack of production facilities so that it has a low level of welfare.

Street vendors who live in poverty are not only low income levels and lack of money for capital, but also get unfair treatment, threats of criminal action, powerlessness in dealing with market thugs and powerlessness in dealing with power (Suryawati, 2005)

\section{MeTHOdOLOGY}

\subsection{Research Paradigm}

The paradigm in this research is social definition. The social definition paradigm views that individual desires are more subjective than objective in seeing social reality, so that the main issue is the individual's willingness as a source of individual action and interaction processes. Thus the actions or behaviors of individuals are based on subjective definitions of individual actors. Thus the powerlessness in self-actualization of street vendors as social realities can be interpreted and understood subjectively by researchers who are associated with the empowerment process carried out on street vendors.

\subsection{Research Approach}

This research approach uses a qualitative research approach. The focus of qualitative research is to explain how social phenomena are formed and given meaning. Thus theoretically this research will shape the meaning of social phenomena related to the powerlessness in PKL self-actualization, so that it will determine the paradigm used by researchers with regard to the orientation of the way of thinking and the way research is conducted.

\subsection{Types of Research}

Phenomenology research is a type of qualitative research method applied to reveal the similarity of meaning which is the essence of a concept or phenomenon that is consciously and individually experienced by a group of individuals in their lives. Phenomenology research aims to illustrate the meaning of life experiences experienced by street vendors in the Palangka Raya City Market which are related to the concept or phenomenon of powerlessness experienced by street vendors in selfactualization.

\subsection{Research Subjects}

The selection of research subjects is based on the subjective principle that masters the problem, has adequate data and is willing to provide complete and accurate information. Criteria for research subjects in the helplessness of street vendors are: (1) actors who know, master and understand the helplessness of street vendors, (2) actors who are involved and involved in street vendor activities, (3) actors who have adequate time to being asked for information, and (4) actors who tend to be able to provide information honestly as it is.

\subsection{Data analysis}


The data processing model used in this study uses an interactive data analysis model from Miles and Huberman consisting of data condensation, data presentation, and drawing conclusions and verification. (1) data condensation, namely the process of selecting, simplifying and changing data resulting from observations, interviews and documentation related to powerlessness in selfactualization of street vendors, (2) data presentation, which is the process of organizing data to facilitate understanding of problems related to powerlessness in self-actualization of street vendors both in the form of narratives, charts and tables, and (3) conclusion and verification of conclusions, namely the process when researchers interpret the research data that is accompanied by making patterns, descriptions and explanations related to powerlessness in self-actualization of street vendors.

\section{RESULTS AND DISCUSSION}

\subsection{Results}

The helplessness of street vendors is one of the problems that can be caused by a variety of factors including the level of education of traders which affects the limitations in self-development of traders including in social interaction and in self-mobility so that it affects the ability of traders to attract and win customers that have an impact on income levels. In addition, the capital factor is one of the causes of underdevelopment and variations in the types of merchandise sold by street vendors, so they are unable to add to the quantity of merchandise due to lack of money. Lack of capital of street vendors can be caused by lack of access in capital. This means that street vendors are very small to get capital from banks that require collateral, while street vendors do not have the collateral required by banks, so getting capital injections is very small or even very difficult. The helplessness of street vendors is reflected in two forms: cultural helplessness and structural helplessness.

\subsubsection{Cultural Powerlessness}

Street vendors in the large market of Palangka Raya consist of various ethnic groups, including Dayak, Banjar, Javanese, Batak, Sundanese, and Minang who certainly have different behaviors and cultures. Behavior and culture that tend to be the same in trading among street vendors behavior resigned to the situation, sell as is, lack of innovation in the way of offering, types of merchandise that tend to be less varied and less attractive packaging.

Pessimistic behavior of traders towards success resulting in low work motivation. Low work motivation makes productivity also low, due to low productivity, it also impacts on a small amount of income. With a small income it will have an impact on the level of life that is mediocre to meet the needs of life. With a mediocre situation it will not be able to increase the number and type of merchandise so it tends to how much can be bought for resale, so that street vendors only seek profit from the difference in price between the purchase price and the selling price. Thus with the amount of funds or capital available, the situation of street vendors remains powerless to make changes in their lives.

Cultural characteristics of street vendors who have low enthusiasm for progress and weak fighting power to change their lives make street vendors unable to develop and advance. Plus the existence of a culture that tends to be oriented to the needs of the present, making street vendors only pursue profits for the needs of the present without innovation and creativity to create opportunities for the continuity and development of the business, including in the context of self-actualization in the future. Even more alarming is that this cultural helplessness can be passed down to the next generation so it makes a cycle of helplessness. The helplessness inherited here is the helplessness caused by the inability of parents to provide proper education due to limited funds, so children do not have the skills and ability to work in the formal sector which makes it look like the condition of their helpless parents.

\subsubsection{Structural Powerlessness}

The condition of the street hawkers in Palangkaraya Large Market not only experienced cultural helplessness but also structurally. They are helpless not because they are lazy to work or lack of hard work, but they are powerless to change their destiny. The narrowness of business opportunities, as well as the lack of opportunities make street vendors trapped in the system. The system is what makes the street vendors become powerless, because the system is less in favor of the street vendors. The business and bureaucratic system has been mastered and ridden by the interests of the ruling elite making business more difficult. Many expenses must be borne by street vendors ranging from renting 
places to sell (shanties), pay for cleaning money, pay security money, pay for parking and pay for lighting lamps.

The helplessness of street vendors is increasingly seen when the City Government of Palangkaraya issues a policy on relocation of street vendors that is less strategic so that it causes loneliness of buyers so that income is reduced. To cope with the lack of buyers, street vendors look for places to sell near the highway, making it easier for buyers to access. But again they were helpless when the Palangkaraya Municipal Civil Service Police Unit put in order so that their shanties and merchandise were transported and taken to the Civil Service Police Unit. They suffer material, time and labor losses that are supposed to sell for income.

Likewise in capital, street vendors lack access to additional capital from banks, because to get a loan from a bank there must be collateral that is pledged so that they are stuck to borrow capital from moneylenders who have to be paid daily, weekly and monthly installments. So the benefits gained by street vendors are only enough to pay off debt and a little to meet their needs. Let alone for selfactualization, to survive is already thankful. The helplessness of street vendors from day to day will continue to be so without any significant changes. The profits and income that they get are not sufficient for the necessities of life let alone to increase business capital. Lack of capital causes low productivity of traders, low productivity results in low income they receive, low income impacts on low savings and investment, and low investment will have implications for powerlessness in selfactualization.

\subsection{Discussion}

Kieffer in Suharto (2005) concretely describes groups that experience powerlessness, namely certain groups that experience discrimination in society such as lower economic classes, poor groups, small businesses, ethnic minorities, women, small farmers, street vendors, generally experiencing powerlessness. The powerlessness in self-actualization of street vendors in Palangkaraya City's Big Market is not uncommon to be seen as deviant, undervalued, and often stigmatized as weak and lazy people as a result of themselves.

The disadvantage experienced by street vendors in Palangkaraya City's Large Market is cultural disempowerment in the form of discrimination in certain aspects of life, as well as structural powerlessness due to injustice from government policies. This was confirmed by Sennet \& Cabb (1972) and Conway (1979) in Suharto (2005) that the powerlessness was caused by the lack of economic security, low political access, weak access to information and technology, lack of capital / financial support and lack of education and the training.

Seeman (1985), Seligman (1972) and Learner (1986) and Suharto (2005) believe that the helplessness experienced by street vendors as a result of the internalization process due to the impact of social interaction in society, so that the less vulnerable street vendors consider themselves weak and helpless because they think so. For Seeman this condition is considered alienation, Seligman named it with helplessness, while Learner termed surplus helplessness.

As Solomon's opinion that the helplessness of street vendors is caused by power blocks that interfere with the development of effective personal and social skills. However, in this study it appears that the helplessness and self-actualization of street vendors are not solely caused by two factors according to Solomon, but rather are caused by values that are believed by traders (cultural) as well as government policies that are less in favor of traders (structural). Nevertheless Soloman's opinion also has a correlation that is that the helplessness of traders is caused by indirect power blocks at the tertiary level namely the personal limitations and technical skills possessed by street vendors.

Solomon in Hikmat (2010) also states that individual helplessness is considered as the inability of individuals to control emotions, skills, skills, knowledge and other material resources in the order of social values. This means that the powerlessness in self-actualization of street vendors in the Palangkaraya City Big Market is a form of inability in the order of social values regarding knowledge, skills and financial resources. Street vendors have not been able to unleash all their potential, actualize themselves through the development of knowledge and skills and the limited availability of capital.

Self-actualization of street vendors will be realized if they can overcome the powerlessness both culturally and structurally as well as power blocks that are direct or indirect as Solomon thought. For this reason, a proper empowerment approach to street vendors is needed. Empowerment approach is 
intended to help street vendors regain their existence and potential in overcoming the helplessness they face in order to develop the ability, knowledge, expertise, skills, structure or power of the bureaucracy.

The approach of empowering street vendors according to Suharto (2005) can be done through three approaches, namely: (1) a micro approach namely empowering through guidance, counseling and crisis intervention aimed at guiding and training street vendors in trading, (2) mezzo approach namely empowering through the merchant group approach as a medium of intervention to increase awareness, knowledge, skills and attitudes of the merchant group so that it has the ability to solve the problems traders face, and (3) the macro approach is a target of change directed at a broad system of policy formulation, social planning, social action, community organizing and development.

Efforts to empower street vendors are intended to build the foundation of social order so that they have self-existence and self-actualization. Thus street vendors can do their business as a form of selfactualization, potential and abilities they have so that they can meet their daily needs and develop their businesses that are more advanced and varied. With the right empowerment can provide social energy for street vendors to rise, improve quality of life, increase productivity, innovation, and creativity which leads to increasing the welfare of street vendors.

\section{CONCLUSION}

The powerlessness in self-actualization of street vendors in the Palangkaraya City Market is not only caused by internal factors but also external factors, as Solomon's hypothesis that helplessness comes from direct and indirect power blocks. The direct power block is a power that comes from government / institutional agents, while the indirect power block is an experience of individual development.

From Solomon's opinion, if it is associated with the results of the study it can be said that helplessness is not solely caused by the strength of direct blocks or indirect blocks but can be categorized as cultural powerlessness and structural powerlessness. Cultural powerlessness is caused by factors of values, norms, perspectives, mentality, lack of confidence and habits of traders, while structural powerlessness is caused by intervention, government / institutional policies and government alignments with the interests of street vendors.

\section{REFERENCES}

[1]. Alisjahbana. Sukidin. (2006). Marginalisasi Sektor Informal Perkotaan. Surabaya: ITS Press.

[2]. Boeree, George. (2008). Dasar-Dasar Psikologi. Yogyakarta: Prismashopie.

[3]. Chambers, Robert. (1983). Pembangunan Desa Mulai Dari Belakang. Jakarta: LP3ES.

[4]. Chambers, Robert. (1994). Poverty and Livelihoods: Whose Reality Counts?. England: Institute of Development Studies University of Sussex Brighton.

[5]. Dillon, H.S. \& Hermanto. (1993). Kemiskinan di Negara Berkembang: Masalah Konseptual dan Global. Prisma No.3 Th. XII (Jakarta: LP3ES)

[6]. Friedman, H, S dan Schustack, M, W. (2006). Kepribadian: Teori Klasik Dan Modern. Jakarta: Erlangga.

[7]. Hambali, A dan Jaenudin, U. (2013). Psikologi Kepribadian. Bandung: CV. Pustaka Setia.

[8]. Hikmat, Harry. (2004). Strategi Pemberdayaan Masyarakat (Edisi Revisi). Bandung: Humaniora Utama Press.

[9]. Hikmat, Harry. (2010). Strategi Pemberdayaan Masyarakat, Edisi Revisi, Cet, ke 5 Bandung: Humaniora Utama Press.

[10]. Huda, Miftahul. (2015). Peran Pendidikan Islam Terhadap Perubahan sosial. Edukasia: Jurnal Penelitian Pendidikan Islam. Vol. 10, No. 1, Februari 2015

[11]. Karafir, Yan Pieter. (1977). Pemupukan Modal Pedagang Kaki Lima: Seri Pernerbitan Fakultas Ilmu-ilmu Sosial. Jakarta: Universitas Indonesia.

[12]. Kartono, Rinikso. (2011). Ketidakberdayaan (Powerlessness) Orang Dengan HIV/ AIDS (ODHA) Di Kota Malang. Jurnal Penelitian dan Pengembangan Kesejahteraan Sosial Vol 16, No 3. September Desember 2011. 295-313.

[13]. Kusuma, Puri dan Putri Dewi. (2012). Pengaruh Tingkat Pendidikan, Pengetahuan, Sikap dan Terpaan Iklan Layanan Masyarakat KB Versi Shireen Sungkar dan Teuku Wisnu di TV terhadap Perilaku KB pada Wanita atau Pria dalam Usia Subur. Jurnal Interaksi Vol.1 No.1 , 46-56

[14]. Lamba, Arung. (2011). Kondisi Sektor Informal Perkotaan dalam Perekonomian Jayapura-Papua. Jurnal Ekonomi Bisnis. Vol 16 No 2, 155-161. 
[15]. Manning, Chris dan Tadjuddin Noer Effendi. (1991). Urbanisasi, Pengangguran, dan Sektor Informal di Kota. Jakarta: Yayasan Obor Indonesia.

[16]. Maslow, Abraham H. (1970). Motivation and Personality. USA: Harper \& Row, Publishers

[17]. Mc. Gee, T. G dan Yeung, Y. M. (1997). Hawkers In Southeast Asian Cities: Planning for The Bazaar Economiy. Canada: International Development Research Centre.

[18]. Morissan. (2010). Psikologi Komunikasi. Bogor: Ghalia Indonesia.

[19]. Narwoko, J. Dwi, dkk. (2010). Sosiologi: Teks Pengantar dan Terapan. Jakarta: Kencana.

[20]. O’Byrne M. Margaret \& Angers P. William. 1961. Jung's Concept of Self- actualization and Teilhard de Chardin's Philosophy. Journal of Religion and Health, volume 11, number 3: 241-251

[21]. Parsons, Ruth J., James D. Jorgensen, Santos H. Hernandez. (1994). The Integration of Social Work Practice. California: Wadsworth, Inc.

[22]. Pitoyo, Agus Joko. (2007). Dinamika Sektor Informal Di Indonesia Prospek , Perkembangan , dan Kedudukannya. Jurnal Populasi, Vol 18 No 2, 129-146.

[23]. Rappaport, J., (1984). Studies in Empowerment: Introduction to the Issue. Prevention In Human Issue. 3 , 1-7. USA.

[24]. Sabarisman, Muslim. (2012). Perubahan Sosial Dalam Pemberdayaan Masyarakat Miskin Perkotaan "Pemberdayaan Melalui KUBE di Kelurahan Sayangsayang Kota Mataram". SOSIOKONSEPSIA Vol. 17, No. 03. Hal. 252-268.

[25]. Seeman, Melvin. (1982). On The Meaning of Alienation. American Sociological Rev. 24:783-91. Los Angeles: University of California.

[26]. Senekal, B.A. (2010). Alienation in Irvine Welsh's Trainspotting. Department of Afrikaans \& Dutch, German \& French University of the Free State. Literator; Vol. 31, No. 1, 19-36.

[27]. Setiono. (2004). Rule of Law (Supremasi Hukum). Surakarta. Magister Ilmu Hukum Program Pascasarjana Universitas Sebelas Maret.

[28]. Suharto, Edi. (2005). Membangun Masyarakat Memberdayakan Rakyat. Bandung: Refika Aditama.

[29]. Suntari, Sri. (2016). Modul Pengembangan Keprofisian Berkelanjutan. Mata Pelajaran Sosiologi. Jakarta: Direktorat Jenderal Guru dan Tenaga Kependidikan Kementerian Pendidikan dan Kebudayaan.

[30]. Suryawati, Chriswardani. (2005). Memahami Kemiskinan Secara Multidimensional. Semarang: Fakultas Kesehatan Masyarakat dan Magister Ilmu Kesehatan Masyarakat Universitas Diponegoro.

[31]. Suyanto, Bagong, (2005). Metode Penelitian Sosial. Jakarta: Kencana Prenada. Media Groupp

[32]. Sztompka, Piotr. (2004). Sosiologi Perubahan Sosial. Jakarta: Prenada Media.

[33]. Wenovska, Hot. (2016). Ketidakberdayaan Masyarakat Tanjung Siambang Dalam Relokasi Pemukiman Penduduk (Naskah Publikasi). Diakses 20 Oktober 2017 dari http://jurnal.umrah.ac.id/wpcontent/uploads/gravity_forms/1-ec61c9cb2 32a03a96d0947c6478e525e/2016/08/JURNAL50.pdf

[34]. Wirutomo, Paulus. (2013). Mencari Makna Pembangunan Sosial: Studi Kasus Sektor Informal di Kota Solo. Jurnal Sosiologi Masyarakat. Vol 18 No 1, 101-120

\section{AUTHORS' BIOGRAPHY}

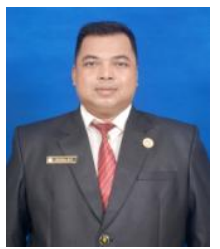

Sriyana was born in Tanggung Grobogan, August 27, 1972, the first child of Mr. Rasiman and Mrs. Kawit. Sriyana is married to Erni Herawati who is blessed with three children namely Fatimatuzzahra Erin Gita Sari, Andhika Prasetya Hidayatullah and Arya Ramadhan Al-Husein. Since 2005 he has been working as a State Civil Apparatus (Lecturer) who has been placed at the University of Kapuas Sintang, West Kalimantan Province, then since 2012 he has moved to the assignment at the University of PGRI Palangkaraya in Central Kalimantan Province until now. Since August 2017 registered as a doctoral student at the University of Muhammadiyah Malang.

Citation: Sriyana, et.al., "Powerlessness in Self-Actualization of Street Vendors in Palangkaraya City" " International Journal of Humanities Social Sciences and Education (IJHSSE), vol 7, no. 6, 2020, pp. 37-45. doi: http://dx.doi.org/10.20431/2349-0381.0706005.

Copyright: () 2020 Authors. This is an open-access article distributed under the terms of the Creative Commons Attribution License, which permits unrestricted use, distribution, and reproduction in any medium, provided the original author and source are credited. 